\title{
Estimation of Carbon Stored in Reforestations in The Mixteca Alta of Oaxaca, Mexico
}

\author{
Abdul Khalil Gardezi ${ }^{1 *}$, Angélica García Jiménez ${ }^{1}$, Sergio R Marquez Berber ${ }^{2}$, Héctor Flores Magdaleno ${ }^{1}$, \\ Mario Ulises Larqué Saavedra ${ }^{3}$ and Gabriel Haro Aguilar $^{1}$ \\ ${ }^{1}$ Postgraduate College in Agricultural Science, Montecillo Campus, México \\ ${ }^{2}$ Crop Science Department, Chapingo Autonomous University, México \\ ${ }^{3}$ Metropolitan Autonomous University, Azcapotzalco, Mexico
}

*Corresponding author: Abdul Khalil Gardezi, Postgraduate College in Agricultural Sciences, Montecillo Campus, México.

Received Date: June 22, 2019

Published Date: June 26, 2019

\begin{abstract}
Background and objective: Mexico is one of the countries with the highest soil degradation due to erosion in Latin America. One of the most affected areas is the Mixteca Alta of Oaxaca, Mexico which presents advanced degradation processes. Where reforestation has been implemented as a restoration strategy. Which will allow recovering some ecosystem functions, such as protection against erosion and carbon capture. Materials and Methods: In the present study, aerial biomass, aerial carbon and soil organic carbon (SOC) were estimated in reforestation of Pinus greggii of different ages ( 1 to 8 years) with soil clearing under two slope conditions in the northern zone of the Mixteca Alta of Oaxaca. Aerial biomass and aerial carbon were obtained by allometric equations. The organic carbon content of the soil was estimated from the soil organic matter (OM), which was evaluated by the method proposed by Walkley and Black [1].
\end{abstract}

Results: The content of aerial biomass and aerial carbon increased with the age of reforestation and varied according to the slope. Finding the highest values in reforestation of 8 years of age on slopes of $1-5^{\circ}(41.08 \pm 1.43$ and $20.95 \pm 0.73)$. In the case of SOC, only the effect of age was observed, with the highest values also being found in reforestation of 8 years of age on slopes of $1-5^{\circ}(23.68 \pm 0.85)$.

Conclusion: Reforestation, in addition to contributing to soil protection against erosion, also has the potential to capture carbon in the aerial biomass and in the soil. Which will be reflected in the quality of the soil and the services that a forestry system can provide.

Keywords: Degradation; Aerial biomass; Allometric equations; Pinus greggii; Soil organic carbon

\section{Introduction}

Soil is the main support for vegetation, infrastructure and habitat of biodiversity and participates in an essential way in the functioning of any ecosystem [2]. However, modern human societies have conceived soils as simple mechanical supports for plants or as sites for establishing human settlements, ignoring their biological, ecological, physical-chemical, socio-economic and cultural importance $[3,4]$. This conception has contributed, together with other factors, to the processes of destruction and degradation that affect the edaphic resource. One of the areas most affected by soil degradation in Mexico is the Mixteca Alta region located in the northern part of the state of Oaxaca which presents advanced processes of degradation and loss of soil by erosion. Tending some areas to include desertification [5]. The problem of degradation and loss of productivity of soils extends, in many cases, beyond the effects on this resource. When areas with forest cover or other natural ecosystems are transformed into crop fields, beside the damage to biodiversity, there is a large loss of carbon stored in both biomass and soil. Therefore, the emission of gases type greenhouse into the atmosphere. Faced with this situation, the National Forestry Commission (CONAFOR), through the National Forestry Program 2014-2018 (PRONAFOR), objective is to promote the recovery of forest cover and the restoration of soils in degraded forest lands devoid of vegetation [6]. In the Mixtec region and specifically in the study area, the actions of CONAFOR 
focus on the integral restoration. That involves the planting of tree species, as well as various actions focused on the recovery of soils as soil conservation works. The reforestation seen as a strategy to achieve the restoration of the degraded lands that have lost the vegetation cover by the different causal agents. Was established with the purpose to protect and contribute to the stabilization and restoration of lands with strong problems of vegetation loss and soil erosion [7]. In addition to the environmental services to provide support and regulation that offers reforestation, its importance is also due to the function of reforestations to capture carbon in its aerial biomass, which is generally studied in natural forests [8-10]. From the economic point of view, these generates income through payment for environmental services [11-14]. Likewise, it contributes to the accumulation of SOC in the soil, but there are few studies on the accumulation dynamics of SOC recently incorporated into the soil as a result of the establishment of reforestation [15]. The objective of this research was to estimate the accumulation of aerial carbon and SOC in reforestations with plowing of soil of different ages ( 1 to 8 years) under two conditions of slope in the northern zone of the Mixteca Alta of Oaxaca, Mexico.

\section{Materials and Methods}

\section{Study area}

The study was conducted in the northern portion of the Mixteca Alta region of the state of Oaxaca (Figure 1), located between the parallels $17^{\circ} 47^{\prime}$ and $17^{\circ} 57^{\prime}$ North latitude and the meridians $97^{\circ} 20^{\prime}$ and $97^{\circ} 31^{\prime}$ West longitude with an altitudinal variation of 2000 and $2200 \mathrm{~m}$. According to the climatic classification of Köppen modified by Enriqueta García [16] the climate is BS1kw, semi-arid, temperate, with average annual temperature between $12^{\circ} \mathrm{C}$ and $18^{\circ} \mathrm{C}$, summer rainfall regime, with an average annual precipitation of $474.7 \mathrm{~mm}$. According to the baseline world reference of the soil resource of the FAO World Reference Base (WRB) used by INEGI the predominant soils in the study area are regosols, vertisols and leptosols; and to a lesser extent phaeozem, luvisols and cambisols. The predominant use of land is induced pasture, there are extensions where vegetation has been lost due to felling or continuous grazing of livestock, which prevents new plants from growing again. The herbaceous stratum, mainly of low height, and some specimen of maguey (Agave sp.), cover the land partially (Figure 1).

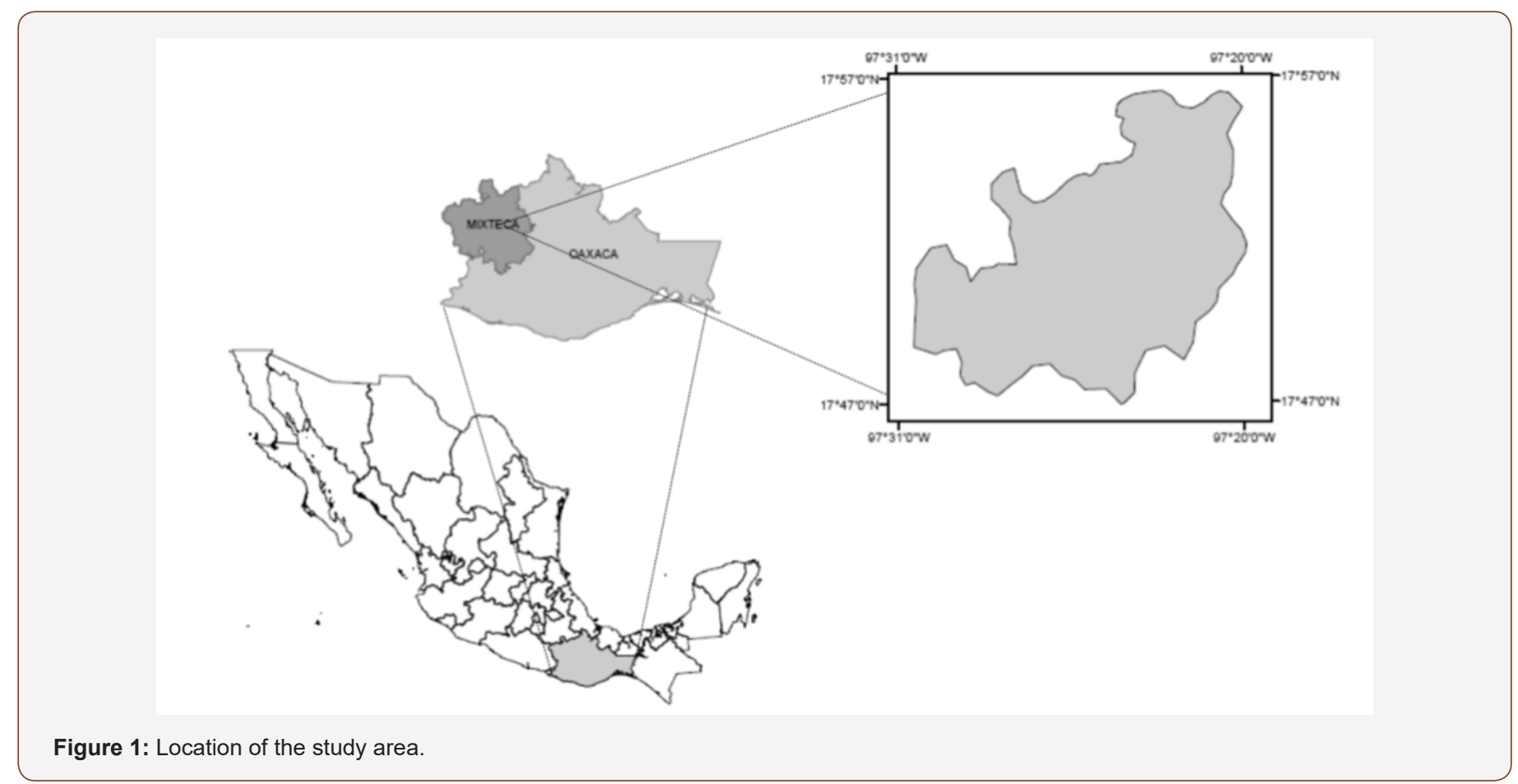

\section{Sampling sites}

Due to the degradation conditions of the place, the best adapted species is Pinus greggii, which is a native species of Mexico and is distributed naturally in isolated populations along the Sierra Madre Oriental. This species has a great potential to adapt to moisture and nutrient limiting conditions, which makes it a species widely used in reforestation programs for the recovery of degraded soils in different parts of Mexico $[17,18]$. Reforestation was established in a planting frame of $3 \mathrm{~m}$ between rows $\mathrm{x} 3 \mathrm{~m}$ between plants, with an average density of 1,100 plants per hectare. The soil preparation consisted of plowing soil in curves at a level $3 \mathrm{~m}$ apart. A fence was also established to serve as protection against livestock, with maintenance after one year of its establishment. Which consists mainly of the reconstruction of a bowl, a work that promotes the capture of water. Reforestation was selected with an average of 1 , $2,3,4,5,6$ and 8 years of age and an area with scarce vegetation (ASV). Under two conditions of slope $\left(1-5^{\circ}\right.$ and $\left.5-15^{\circ}\right)$ where 3 sampling sites of $400 \mathrm{~m} 2$ of circular shape (radius of $11.28 \mathrm{~m}$ ) were randomly established.

\section{Biomass and $C$ content in trees}

All plants that were found in the sampling sites were measured, the total height (TH) with the help of a telescopic rod and the normal diameter (ND) and diameter to the base (DB) with a precision vernier $(0.1 \mathrm{~mm})$. To calculate aerial biomass and total air carbon 
of P. greggii, models generated for the same species proposed by Pacheco et al., [19].

$$
\mathrm{Bt}=6426.6\left(D^{2} h\right)^{2}+291.42\left(D^{2} h\right)
$$

where: Bt is the total biomass in $\mathrm{kg} /$ tree, D is the normal diameter and $\mathrm{h}$ is the total height.

$$
\mathrm{Ct}=3287.7\left(\mathrm{D}^{2} \mathrm{~h}\right)^{2}+147.36\left(\mathrm{D}^{2} \mathrm{~h}\right)
$$

where: $\mathrm{Ct}$ is the total carbon in $\mathrm{kg} /$ tree, D is the normal diameter and $\mathrm{h}$ is the total height.

Once the biomass and carbon data of each tree were obtained, they were added to obtain estimates at plot level and finally, by extrapolation, the biomass per unit area was estimated.

\section{Content of $\mathrm{C}$ in soil}

At each site, the sampling was carried out in a transect oriented towards the slope, in which, with the help of a straight shovel, 3 subsamples were taken and a composite sample of soil of approximately $500 \mathrm{~g}$ was formed, which was deposited in a plastic bag and properly labeled. Subsequently, the samples were sent to the Central University Laboratory of the Autonomous University of Chapingo, Mexico for analysis. Where the percentage of M.O. [1] and the Dap (paraffin method), based on the Official Mexican Standard NOM-021-SEMARNAT-2000 [20]. Once the percentage of M.O. was determine by the Van Benmelen factor of 1,724 a correction was applied, resulting from the assumption that soil organic matter contains 58\% Carbon ( $1 / 0.58=1.724)$. Finally, the SOC content per unit area $\left(\mathrm{Mg} \mathrm{ha}^{-1}\right)$ was calculated based on the equation proposed by González et al., [21].

$$
\text { SOC=CO (Dap) Ps }
$$

where: SOC is the total organic carbon in soil per surface (Mg ha$\left.{ }^{1}\right)$, SOC is the total organic carbon in\%, Dap is the apparent density $\left(\mathrm{g} \mathrm{cm}^{-3}\right)$ and Ps is the soil depth in $\mathrm{cm}$.

\section{Statistical analysis}

The variation of survival, normal diameter, diameter to base, total height, aerial biomass, aerial carbon and SOC were explored through the analysis of variance of two factors (age and slope). When a factor was significant, mean comparisons were made with the Tukey test. All the analyzes were performed with the statistical package InfoStat with a confidence level of $95 \%$.

\section{Results and Discussion}

According to the variance analysis, both the TH and the ND presented significant differences only due to the independent effect of the age and slope factors, while the DB only presented significant differences due to the independent effect of the age factor and the $S$ only due to the effect independent of the pending factor (Tables $1 \& 2)$.

\begin{tabular}{|c|c|c|c|c|c|c|}
\hline Age & Slope & ${ }^{\Phi} \mathbf{D}$ & $\phi \Phi S$ & ${ }^{\varphi} \mathrm{DB}$ & ${ }^{\varphi \varphi} \mathrm{ND}$ & $\dagger \mathrm{TH}$ \\
\hline Years & $\circ$ & $\mathrm{N}^{* *}$ ha $^{-1}$ & $(\%)$ & $(\mathrm{cm})$ & $(\mathrm{cm})$ & $(\mathrm{m})$ \\
\hline \multirow{2}{*}{1} & 01-May & $670.00 \pm 43$ & $60.91 \pm 3.96$ & $1.41 \pm 0.21$ & & $0.50 \pm 0.05$ \\
\hline & May-15 & $908.33 \pm 96$ & $82.58 \pm 8.74$ & $1.37 \pm 0.26$ & & $0.55 \pm 0.06$ \\
\hline \multirow{2}{*}{2} & 01-May & $683.33 \pm 54$ & $62.12 \pm 4.97$ & $2.81 \pm 0.11$ & & $1.26 \pm 0.11$ \\
\hline & May-15 & $850.00 \pm 86$ & $77.27 \pm 7.87$ & $2.72 \pm 0.06$ & & $1.13 \pm 0.19$ \\
\hline \multirow{2}{*}{3} & 01-May & $858.00 \pm 54$ & $78.00 \pm 4.99$ & $3.72 \pm 0.65$ & & $2.24 \pm 0.35$ \\
\hline & May-15 & $708.33 \pm 23$ & $64.39 \pm 2.14$ & $2.43 \pm 0.16$ & & $1.53 \pm 0.22$ \\
\hline \multirow{2}{*}{4} & 01-May & $681.00 \pm 31$ & $61.91 \pm 2.84$ & & $5.03 \pm 0.55$ & $3.45 \pm 0.66$ \\
\hline & May-15 & $783.33 \pm 83$ & $71.21 \pm 7.58$ & & $2.82 \pm 0.40$ & $2.57 \pm 0.18$ \\
\hline \multirow{2}{*}{5} & 01-Мау & $792.00 \pm 59$ & $72.00 \pm 5.43$ & & $5.78 \pm 0.36$ & $4.27 \pm 0.43$ \\
\hline & May-15 & $1025.00 \pm 14$ & $93.18 \pm 1.31$ & & $5.04 \pm 0.31$ & $4.00 \pm 0.30$ \\
\hline \multirow{2}{*}{6} & 01-May & $876.67 \pm 14$ & $79.70 \pm 1.32$ & & $7.76 \pm 0.15$ & $5.82 \pm 0.92$ \\
\hline & May-15 & $871.67 \pm 61$ & $79.24 \pm 5.61$ & & $6.53 \pm 0.28$ & $4.82 \pm 0.49$ \\
\hline \multirow{2}{*}{7} & 01-May & $733.33 \pm 8$ & $66.67 \pm 0.76$ & & $9.17 \pm 0.51$ & $6.47 \pm 0.20$ \\
\hline & May-15 & $750.00 \pm 43$ & $68.18 \pm 3.94$ & & $8.48 \pm 0.07$ & $5.49 \pm 0.51$ \\
\hline
\end{tabular}

Table 1: shows the results of the variables plantation density (D), survival (S), diameter at the base (DB), normal diameter (DN) and total height (AT) present in the reforestations evaluated.

$\phi D$ : planting density; $\phi \phi$ Survival; $\varphi \mathrm{DB}$ : diameter to the base; $\varphi \varphi N D$ : normal diameter; $\uparrow \mathrm{TH}$ : total height; $\uparrow \dagger \mathrm{N}$ : number of trees. Stocks \pm Standard Error.

Table 2: Analysis of variance of the variables; survival, total height, normal diameter, diameter at the base and total height.

\begin{tabular}{|c|c|c|c|c|c|c|}
\hline \multirow{2}{*}{ Variable } & $\begin{array}{c}\text { Source of } \\
\text { Variation }\end{array}$ & Degree Freedom & Sum of Squares & Average Squares & F Calculated & Value p \\
\hline \multirow{3}{*}{ Survival (\%) } & Model. & 13 & 3461.02 & 266.23 & 3.51 & 0.0026 \\
\cline { 2 - 8 } & Age & 6 & 1328.23 & 221.37 & 2.92 & 0.0645 \\
\cline { 2 - 8 } & Slope & 1 & 642.51 & 642.51 & 8.47 & 0.007 \\
\cline { 2 - 8 } & Age*Slope & 6 & 1490.27 & 248.38 & 3.27 & 0.0844 \\
\hline
\end{tabular}




\begin{tabular}{|c|c|c|c|c|c|c|}
\hline \multirow{4}{*}{ Total Height (m) } & Model. & 13 & 161.18 & 12.4 & 24.61 & $<0.0001$ \\
\hline & Age & 6 & 156.17 & 26.03 & 51.66 & $<0.0001$ \\
\hline & Slope & 1 & 3.28 & 3.28 & 6.52 & 0.0164 \\
\hline & Age*Slope & 6 & 1.72 & 0.29 & 0.57 & 0.7506 \\
\hline \multirow{4}{*}{$\begin{array}{l}\text { Normal Diameter } \\
\qquad(\mathrm{cm})\end{array}$} & Model. & 7 & 92.18 & 13.17 & 32.98 & $<0.0001$ \\
\hline & Age & 3 & 81.01 & 27 & 67.63 & $<0.0001$ \\
\hline & Slope & 1 & 8.95 & 8.95 & 22.43 & 0.0002 \\
\hline & Age*Slope & 3 & 2.22 & 0.74 & 1.85 & 0.1782 \\
\hline \multirow{4}{*}{$\begin{array}{l}\text { Diameter to the } \\
\text { base }(\mathrm{cm})\end{array}$} & Model. & 5 & 12.14 & 2.43 & 8.38 & 0.0013 \\
\hline & Age & 2 & 9.66 & 4.83 & 16.66 & 0.0003 \\
\hline & Slope & 1 & 1.01 & 1.01 & 3.47 & 0.0871 \\
\hline & Age*Slope & 2 & 1.48 & 0.74 & 2.55 & 0.119 \\
\hline
\end{tabular}

\section{Effect of age on the growth of Pinus greggii}

In general, the growth variables (DB, ND and $\mathrm{TH}$ ) as a function of age had a positive behavior, that is to say, as the age of the reforestation increases, it also increases DB, ND and TH. Muñoz et al., [22] also found that the height and normal diameter of trees increased with age in a Pinus greggii plantation in the Sierra Purépecha in Michoacán, Mexico. Figure 2 shows the average TH of the trees by age and their standard error. The highest TH is reported for reforestation of 8 years with an average of $5.98 \mathrm{~m}$ and the lowest TH for one-year reforestations with an average of $0.53 \mathrm{~m}$.

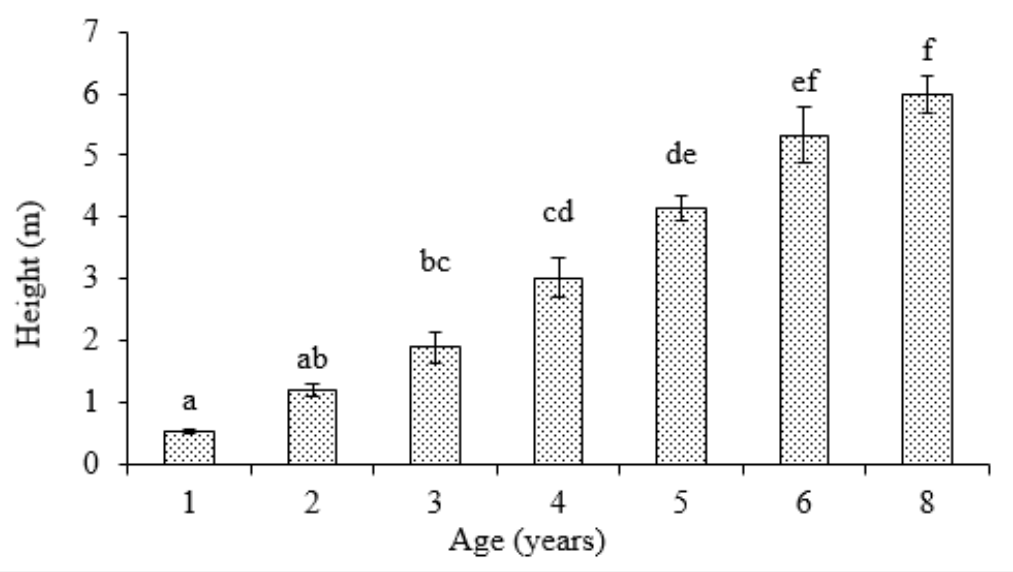

Figure 2: Total height of Pinus greggii in reforestation of different ages (1 to 8 years) in the Mixteca Alta of Oaxaca. Error bars indicate standard error. Columns with different letters are statistically different (Tukey, $\mathrm{P}<0.05$ ).
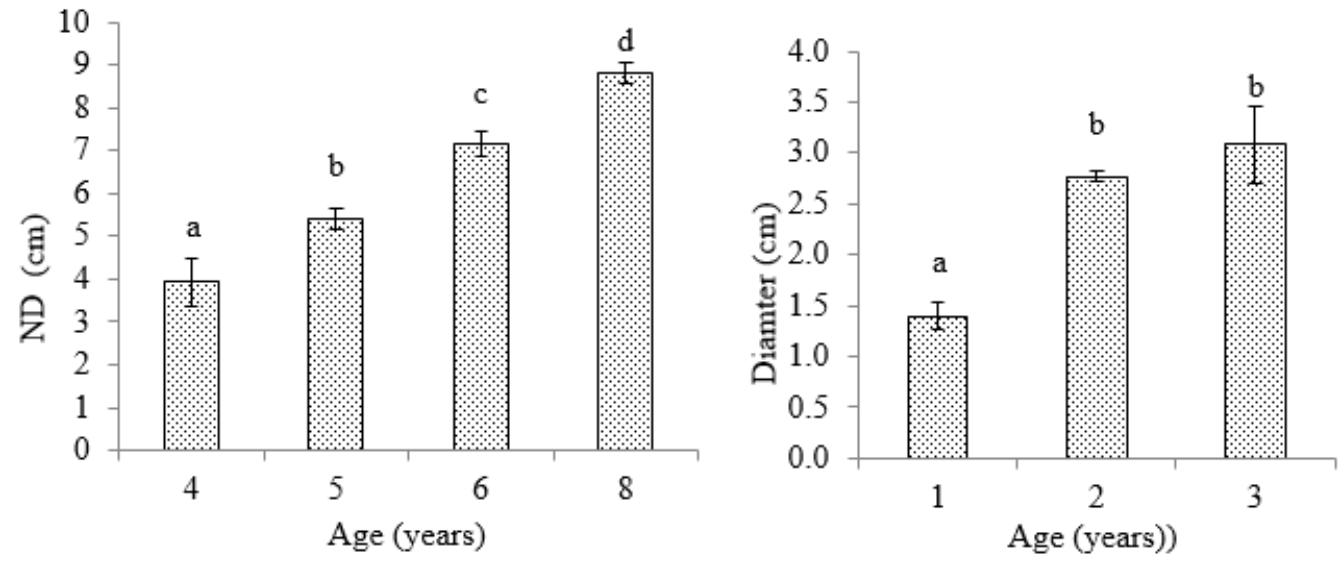

Figure 3: Normal diameter and diameter at the base of Pinus greggii in reforestation of different ages (1 to 8 years) in the Mixteca Alta of Oaxaca. Error bars indicate standard error. Columns with different letters are statistically different (Tukey, $\mathrm{P}<0.05)$.

The ND of Pinus greggii also varied significantly between ages, being statistically different in all ages. Figure 3: shows the average ND of the trees by age and their standard error. The highest ND is reported for reforestation of 8 years with an average of $8.83 \mathrm{~cm}$, while the smallest diameter is reported for reforestation of 4 years with an average of $3.93 \mathrm{~cm}$. As for the DB, as in the TH and ND there 
were significant differences between the ages, being statistically equal in ages of 3 and 2 years, but different for 1 year. Figure 3 shows the average DB of the trees by age and their standard error. The highest DB is reported for reforestation of 3 years with an average of $3.08 \mathrm{~cm}$ while the lowest DB is reported for reforestation of 1 year with an average of $1.40 \mathrm{~cm}$.

\section{Effect of the slope on survival and growth}

Survival presents a trend in which, on steeper slopes, there is greater survival (Figure 4), but lower growth. This coincides with what was reported by Gómez-Romero et al., [23], in plantations of P. cembroides, P. greggii, P. devoniana and P. pseudostrobus established in severely degraded sites of Michoacán, Mexico. He found that the lower the survival, the lower the growth in diameter of the species, and at higher slope, greater survival, but smaller diameter.

In the case of the effect of the slope, the TH and ND had a negative behavior, that is to say, as the degree of slope increases, the TH and the ND decrease. Observing significant differences between the two slope conditions $\left(1-5^{\circ}\right.$ and $\left.5-15^{\circ}\right)$ (Figure 4$)$. The DB was not influenced by the effect of the slope. The slope of $1-5^{\circ}$ presents higher TH and ND with $3.43 \mathrm{~m}$ and $6.94 \mathrm{~cm}$ respectively. These results agree with what was reported by Gómez-Romero et al., [23]. This behavior may be due to the fact that steeper slopes are less exposed to solar rays, and therefore more humid and with lower temperatures [24] thus achieving greater survival of individuals, which causes greater competition by nutrients and light, causing these individuals to grow less. It can also be attributed to the fact that soils on higher slopes are more degraded and consequently less fertile.

A good growth of Pinus gregii is observed according to its age, this can be attributed to the fact that this species adapts to adverse conditions of the environment, such as its growth in low fertility or degraded soils, thus being a potential species for programs of restoration $[25,26]$. In addition, the growth could also have been favored by the management that is given to the reforestations, as maintenance after a year of its establishment. Which consists mainly of the reconstruction of a bowl, work that promotes the storage of water, the plowing soil that allows greater infiltration of water and penetration of the roots, as well as the fence that serves as protection against livestock.

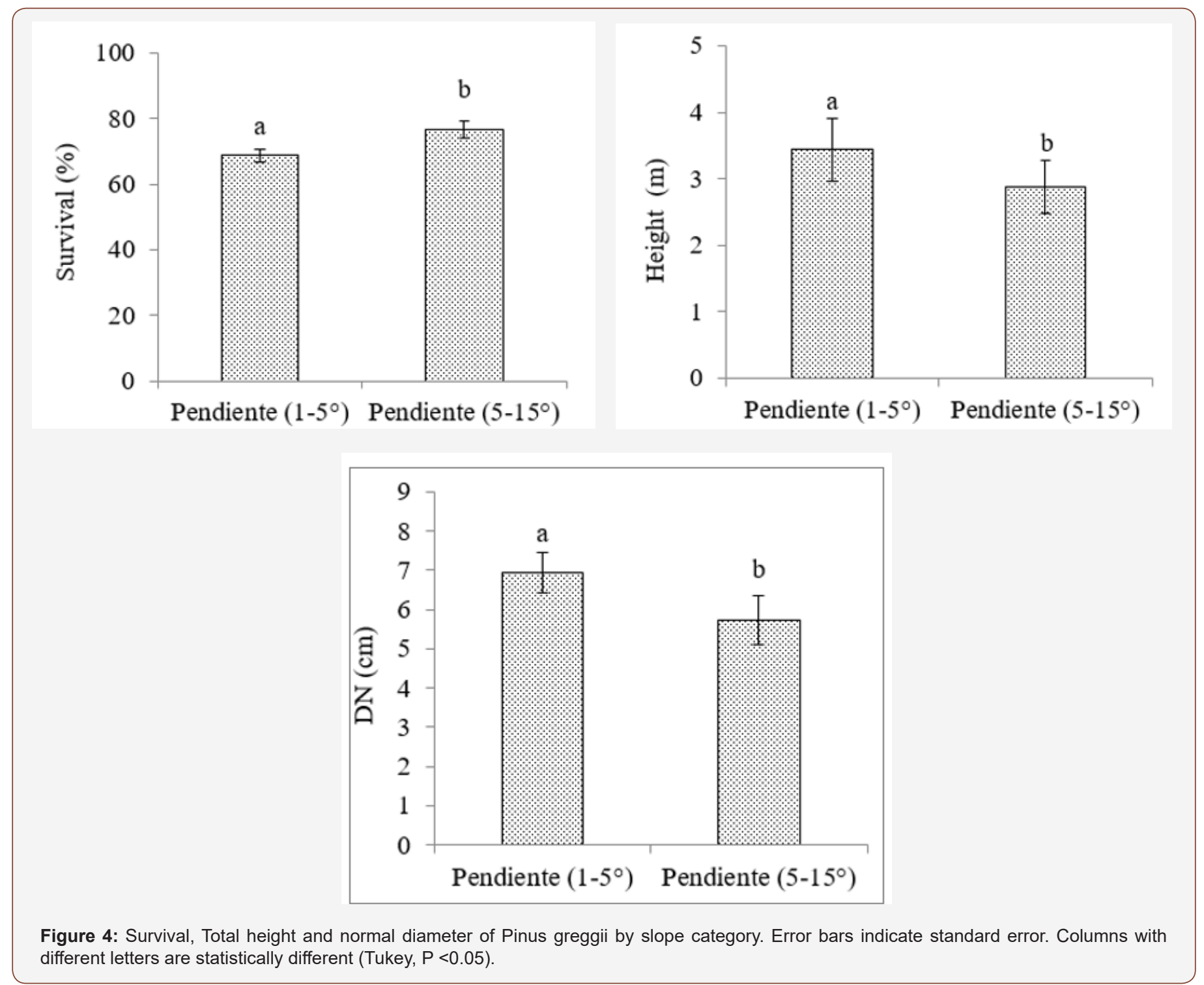




\section{Biomass and aerial carbon content}

In Table 3, the biomass content ( $\left.\mathrm{Mg} \mathrm{ha}^{-1}\right)$ and air carbon (Mg ha $^{-1}$ ) in reforestation of Pinus greggii of various annuities (4 to 8 years), under two slope conditions $\left(1-5^{\circ}\right.$ y $\left.5-15^{\circ}\right)$. For reforestation of one to three years, there are no values of aerial biomass, because the existing equations for estimating biomass and carbon for the species use the ND and TH as predictor variables, and for the ages of 1 to 3 years the ND is not registered yet.

Table 3: Biomass and aerial carbon content in reforestation of Pinus greggii in the Mixteca Alta of Oaxaca, Mexico.

\begin{tabular}{|c|c|c|c|}
\hline Age & Slope & Biomass & Carbon \\
\hline Years & $\circ$ & \multicolumn{2}{|c|}{------- (Mg ha-1) ----------- } \\
\hline \multirow{2}{*}{4} & 01-May & $3.57 \pm 0.38$ & $1.82 \pm 0.20$ \\
\hline & May-15 & $0.96 \pm 0.19$ & $0.49 \pm 0.10$ \\
\hline \multirow{2}{*}{5} & 01-May & $7.99 \pm 0.74$ & $4.07 \pm 0.38$ \\
\hline & May-15 & $7.29 \pm 0.44$ & $3.72 \pm 0.23$ \\
\hline \multirow{2}{*}{6} & 01-May & $36.06 \pm 5.10$ & $18.39 \pm 2.60$ \\
\hline & May-15 & $16.41 \pm 1.24$ & $8.37 \pm 0.63$ \\
\hline \multirow{2}{*}{8} & 01-May & $41.08 \pm 1.43$ & $20.95 \pm 0.73$ \\
\hline & May-15 & $33.94 \pm 3.22$ & $17.30 \pm 1.64$ \\
\hline
\end{tabular}

Means \pm Standard Error $(n=3)$.

Pacheco-Escalona et al., [27] reported values of biomass and aerial carbon of 35.2 and $17.9 \mathrm{Mg} \mathrm{ha}^{-1}$ in plantations of P. greggii of six years of age. Which resembles what was found in this study 36.06 and $18.39 \mathrm{Mg} \mathrm{ha}^{-1}$ of biomass and aerial carbon respectively for the plantation of six years on a slope of 1 to $5 \%$. Ventura-Ríos et al., [28] reported $12.17 \mathrm{Mg} \mathrm{ha}^{-1}$ and $14.16 \mathrm{Mg} \mathrm{ha}^{-1}$ of biomass for reforestation of $P$. greggii of 12 and 14 years respectively. Comparing these results with those obtained in the present study, it can be seen that almost twice as much biomass was obtained in younger reforestations. The differences found with this study can be attributed to biotic factors such as sun exposure, soil conditions, quality and site management, and nutrient availability [29-31], which vary from one location to the other. As well as the methodology used to estimate this variable. Which can influence the growth response and biomass accumulation of plant species $[32,33]$.

According to the analysis of variance (Table 4), the biomass and aerial carbon content were significantly affected by the individual effects of age and slope factors and their interaction.

Table 4: Variance analysis of the biomass and aerial carbon variables.

\begin{tabular}{|c|c|c|c|c|c|c|}
\hline Variable & Source of Variation & G.L. & Sum of Squares & Average Squares & F Calculated & P Value \\
\hline \multirow{4}{*}{ Biomass } & Model. & 7 & 5482.89 & 783.27 & 50.83 & $<0.0001$ \\
\cline { 2 - 7 } & Age & 3 & 4816.11 & 1605.37 & 104.19 & $<0.0001$ \\
\cline { 2 - 7 } & Slope & 1 & 339.82 & 339.82 & 22.05 & 0.0002 \\
\cline { 2 - 7 } & Age*Slope & 3 & 326.95 & 108.98 & 7.07 & 0.0031 \\
\hline \multirow{3}{*}{ Aerial Carbon } & Model. & 7 & 1426.10 & 203.73 & 104.19 & $<0.0001$ \\
\cline { 2 - 7 } & Age & 3 & 1252.67 & 417.56 & 22.05 & 0.0001 \\
\cline { 2 - 7 } & Slope & 1 & 88.39 & 88.39 & 28.0002 & 0.0031 \\
\cline { 2 - 7 } & Age*Slope & 3 & 85.04 & & & 2.07 \\
\hline
\end{tabular}

\section{Behavior of biomass and aerial carbon according to age}

The amount of biomass presented significant differences between the ages, being statistically equal in ages of 4 and 5 years, but different for both 6 and 8 years. Figure 5 shows the biomass content by age and its standard error. The highest biomass content is reported for reforestation of 8 years with an average of 37.52 $\mathrm{Mg} \mathrm{ha} \mathrm{h}^{-1}$ while the lowest content is reported for reforestation of 4 years with an average of $2.27 \mathrm{Mg} \mathrm{ha}^{-1}$. The aerial carbon content presented a similar behavior to the biomass, that is to say, it presented significant differences between the ages, being statistically equal in ages of 4 and 5 years, but different for both 6 and 8 years. Figure 5 shows the air carbon content by age and its standard error. The highest aerial carbon content is reported for reforestation of 8 years with an average of $19.13 \mathrm{Mg} \mathrm{ha}^{-1}$ while the lowest content is reported for 4-year reforestation with an average of $1.16 \mathrm{Mg} \mathrm{ha}^{-1}$.

The carbon and biomass content as a function of age had a positive behavior, that is, as the age of reforestation increases, the carbon and biomass content increase. Similar results were found by Oliva et al., [34], in their study of Pinus patula, where the biomass and carbon of this species increased gradually as age increased. These results also agree with those obtained by Li et al., [35] who examined the biomass and carbon deposits in plantations of $\mathrm{P}$. koraiensis in a chrono sequence, observing that the aerial and total biomass increased with the age of the plantations. On the other hand, Chávez-Aguilar et al., [36], reports that the production of total aerial biomass of Pinus patula increased during the chrono sequence. However, in the first stages of development of the stand 
no statistical differences were found between the annuities, but from 24 years. This behavior in both biomass and carbon can be explained because trees absorb $\mathrm{CO}_{2}$ from the atmosphere in the process of photosynthesis and use it to synthesize sugars and other organic compounds used in growth and metabolism. However, the rate of $\mathrm{CO}_{2}$ fixation by trees is not uniform throughout their life but is directly related to their growth.

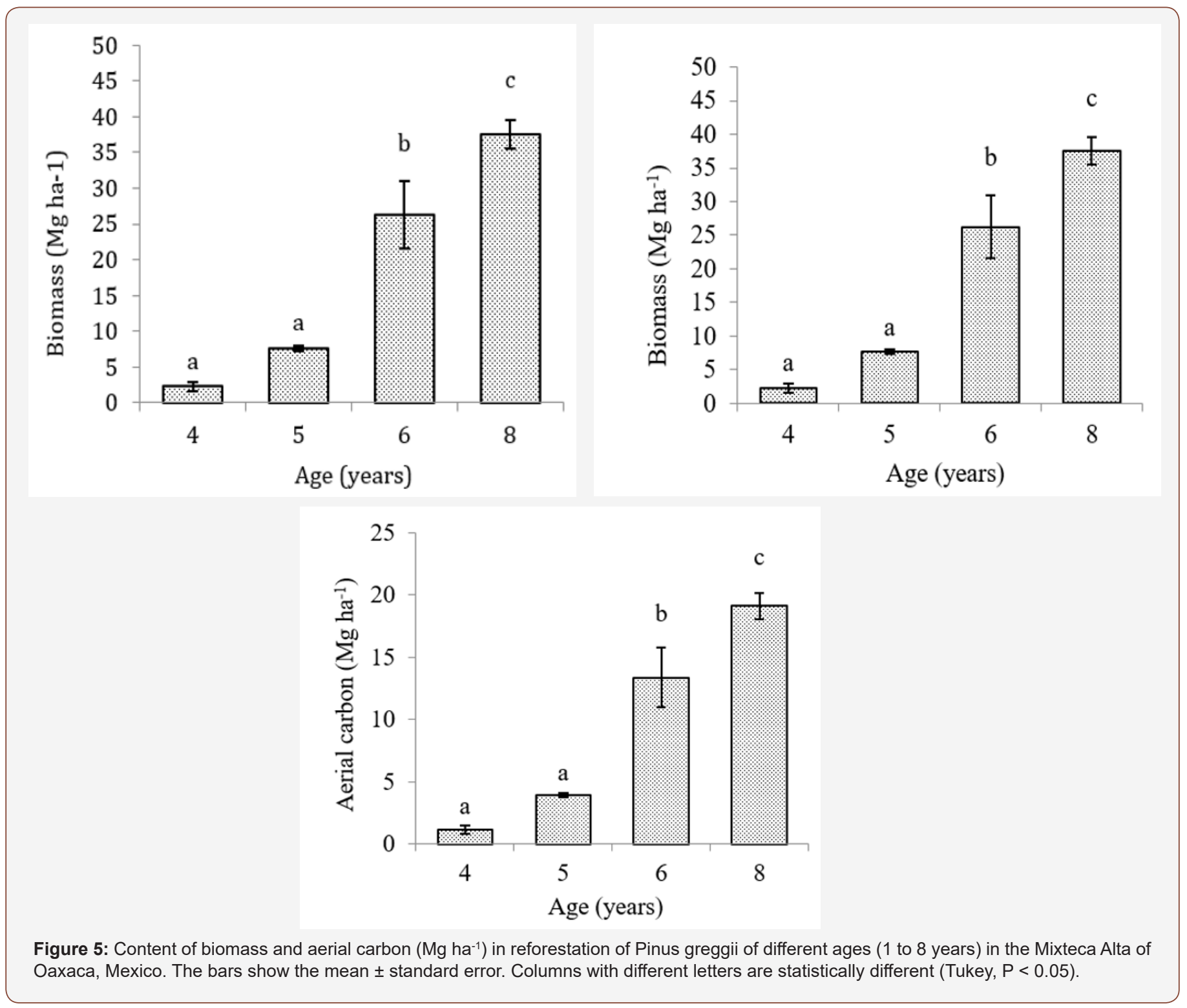

Behavior of biomass and aerial carbon depending on the slope
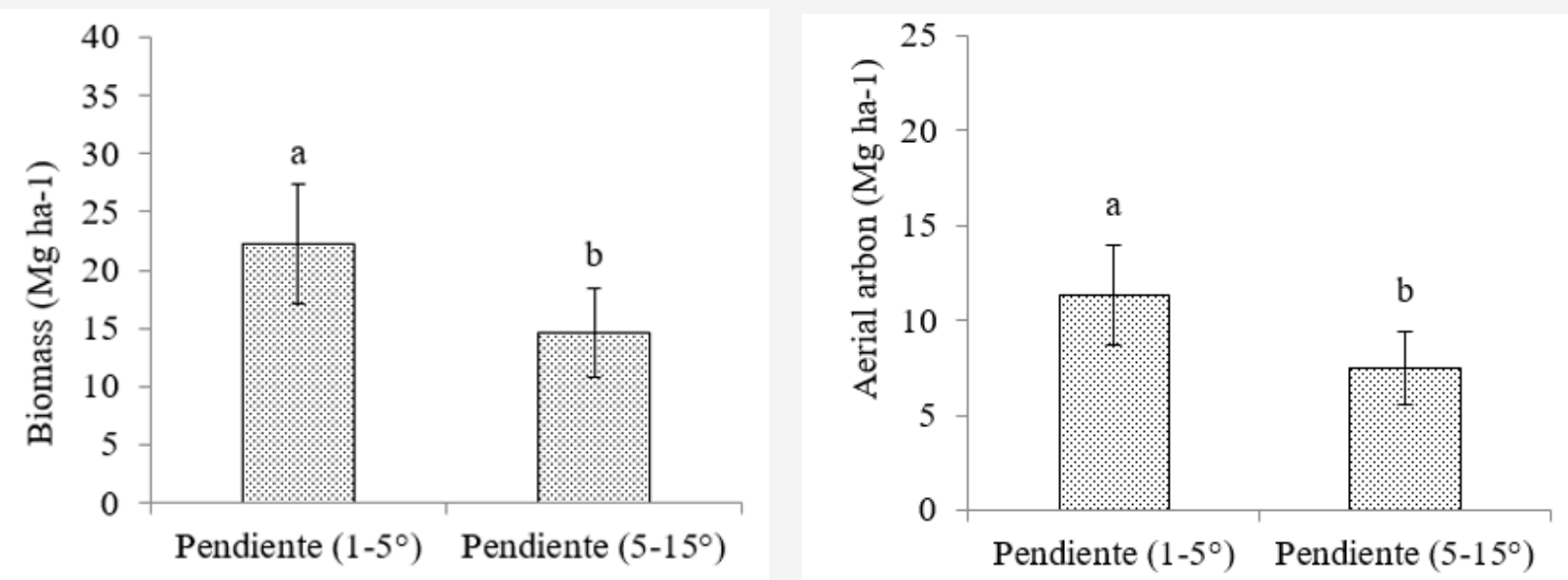

Figure 6: Biomass and aerial carbon content in reforestation of Pinus greggii in two slope conditions in the Mixteca Alta of Oaxaca, Mexico. The bars show the mean \pm standard error. Columns with different letters are statistically different (Tukey, $P<0.05)$. 
In this study it can be observed that the production of the biomass and consequently the aerial carbon is also related to the slope. On slopes of $1-5^{\circ}$, biomass and aerial carbon contents of 22.18 $\mathrm{Mg} \mathrm{ha}^{-1}$ and $11.31 \mathrm{Mg} \mathrm{ha}^{-1}$ respectively were recorded, while on slopes of $5-15^{\circ}$ biomass and aerial carbon contents of 14.66 $\mathrm{Mg} \mathrm{ha}^{-1}$ and $7.47 \mathrm{Mg} \mathrm{ha}^{-1}$ were recorded (Figure 6). It is observed that the content of biomass and aerial carbon in slopes of $1-5^{\circ}$ is almost double than that found in slopes of $5-15^{\circ}$. Similar results were found by Sattler et al., [37] in a reforestation established in abandoned pasture areas in Brazil where trees planted on slopes stored only half the carbon than trees planted on flat land.

In the same way, Lin et al., [38] found greater accumulation of flat slope biomass than on steep slopes in a subtropical forest in China. This result differs with that reported by García-Agilar et al., [39] who found significant differences by the effect of altitude and exposure, but not by the degree of slope in a pine-oak forest in the Sierra Norte of Oaxaca, Mexico. The behavior presented in this study is attributed to the fact that greater growth was observed in trees on lower slopes, which translates into greater production of biomass and aerial carbon.

\section{Behavior of biomass and aerial carbon as a function of age - slope}

Both the biomass content and the aerial carbon showed significant differences due to the age-slope effect. Figure 7 shows the biomass and aerial carbon content by age and slope condition, as well as its standard error. The trend is observed where lower slope higher biomass production in the different ages, however, only significant differences are found for reforestation of 6 years of age.

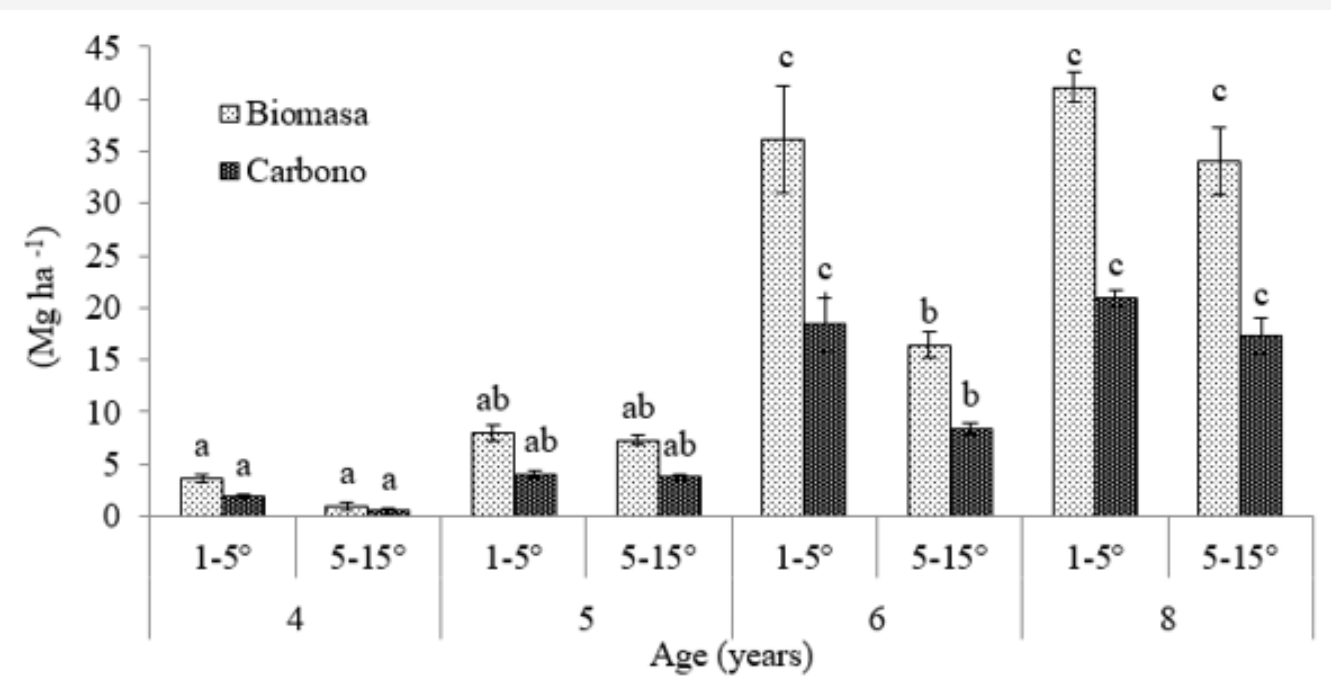

Figure 7: Biomass and aerial carbon content in reforestation of Pinus greggii of different ages in two slope conditions. The bars show the mean \pm standard error. Columns with different letters are statistically different (Tukey, $\mathrm{P}<0.05$ ).

\section{Organic soil carbon}

In Table 5, the values of the organic carbon content of the estimated soil $\left(\mathrm{Mg} \mathrm{ha}^{-1}\right)$ are shown. The lowest SOC content was observed in areas with little vegetation. Castillo-Pacheco et al., [40] report carbon values for bare soils of $16.31 \mathrm{Mg} \mathrm{ha}^{-1}$, higher than the value registered in ASV in this study. The highest content was found in soils associated with reforestations of 8 years of age on slopes of $1-5 \%$ and $5-15 \%$ respectively.

Table 5: Organic carbon content in soils associated with reforestation of Pinus greggii in the Mixteca Alta of Oaxaca, Mexico at a depth of 0-10 cm.

\begin{tabular}{|c|c|c|c|c|c|}
\hline Age & Slope & ${ }^{\Phi} \mathrm{AD}$ & ${ }^{\phi \Phi} \mathrm{OM}$ & ${ }^{\varphi} \mathrm{SOC}$ & SOC \\
\hline Years & $\%$ & $\mathrm{~g} \mathrm{~cm}^{-3}$ & $\%$ & $\%$ & $\mathrm{Mg} \mathrm{ha}^{-1}$ \\
\hline \multirow{2}{*}{1} & 01-May & $1.01 \pm 0.03$ & $1.91 \pm 0.21$ & $1.11 \pm 0.12$ & $10.29 \pm 0.99$ \\
\hline & May-15 & $1.05 \pm 0.06$ & $1.82 \pm 0.17$ & $1.05 \pm 0.10$ & $10.23 \pm 0.51$ \\
\hline \multirow{2}{*}{2} & 01-May & $1.05 \pm 0.07$ & $2.22 \pm 0.08$ & $1.28 \pm 0.05$ & $11.22 \pm 1.47$ \\
\hline & May-15 & $1.04 \pm 0.06$ & $2.13 \pm 0.08$ & $1.23 \pm 0.05$ & $10.97 \pm 0.87$ \\
\hline \multirow{2}{*}{3} & 01-May & $1.06 \pm 0.06$ & $2.36 \pm 0.19$ & $1.37 \pm 0.11$ & $13.63 \pm 0.56$ \\
\hline & May-15 & $1.08 \pm 0.03$ & $2.33 \pm 0.13$ & $1.35 \pm 0.07$ & $12.91 \pm 0.41$ \\
\hline \multirow{2}{*}{4} & 01-May & $1.00 \pm 0.04$ & $2.73 \pm 0.12$ & $1.58 \pm 0.07$ & $14.42 \pm 0.25$ \\
\hline & May-15 & $1.17 \pm 0.06$ & $2.77 \pm 0.18$ & $1.60 \pm 0.10$ & $14.68 \pm 0.90$ \\
\hline \multirow{2}{*}{5} & 01-May & $0.96 \pm 0.01$ & $3.10 \pm 0.12$ & $1.79 \pm 0.07$ & $15.90 \pm 0.60$ \\
\hline & May-15 & $0.93 \pm 0.01$ & $3.14 \pm 0.23$ & $1.82 \pm 0.13$ & $18.73 \pm 1.23$ \\
\hline \multirow{2}{*}{6} & 01-May & $1.00 \pm 0.02$ & $3.66 \pm 0.09$ & $2.12 \pm 0.05$ & $17.25 \pm 0.65$ \\
\hline & May-15 & $0.95 \pm 0.05$ & $3.30 \pm 0.26$ & $1.91 \pm 0.15$ & $16.99 \pm 0.60$ \\
\hline
\end{tabular}




\begin{tabular}{|c|c|c|c|c|c|}
\hline 8 & 01 -May & $1.00 \pm 0.06$ & $4.06 \pm 0.20$ & $2.35 \pm 0.12$ & $21.33 \pm 1.97$ \\
\hline & May-15 & $1.04 \pm 0.01$ & $3.56 \pm 0.09$ & $2.06 \pm 0.05$ & $18.20 \pm 0.68$ \\
\hline \multirow{2}{*}{$*$ ASV } & 01 -May & $1.20 \pm 0.01$ & $1.47 \pm 0.12$ & $0.85 \pm 0.07$ & $23.68 \pm 0.85$ \\
\cline { 2 - 6 } & May-15 & $1.26 \pm 0.03$ & $1.39 \pm 0.11$ & $0.80 \pm 0.06$ & $21.65 \pm 0.99$ \\
\hline
\end{tabular}

$\phi A D$ : Apparent density; $\phi ф O M$ : organic matter; $\varphi S O C$ : soil organic carbon; $\uparrow A S V$ : area with scare vegetation. Means \pm Standard Error $(n=3)$.

According to the analysis of variance for the SOC content, no significant effects were observed due to the age-pending interaction or the individual effect of the pending factor, but for the individual effect of the age factor (Table 6). These results differ with that reported by Avilés et al., [41], who found that the SOC values in $\mathrm{T} \mathrm{C} \mathrm{ha-1}$, presented significant differences between the different

Table 6: Variance analysis of the organic carbon content.

\begin{tabular}{|c|c|c|c|c|c|}
\hline Source of Variation & Sum of Squares & G. L & Average Squares & F Calculated & P Value \\
\hline Model. & 799.9 & 15 & 53.33 & 20.02 & $<0.0001$ \\
\hline Age & 765.88 & 7 & 109.41 & 41.08 & $<0.0001$ \\
\hline Slope & 2.11 & 1 & 2.11 & 0.79 & 0.3801 \\
\hline Age*Slope & 31.92 & 7 & 4.56 & 1.71 & 0.1414 \\
\hline
\end{tabular}

The content of SOC varied significantly between ages, in particular it was higher at ages of 6 and 8 years, than at ages of 4 and 5 years and these in turn were higher than those at 3, 2 and 1 years geofoams. The fact that there is no significant difference of SOC by the degree of slope may be due to the fact that compared to other works where a high zone is distinguished from a low zone, in this study there is no gradient of marked slope. SOC behavior according to age.
(Figure 8). The highest SOC content is reported for reforestation of 8 years with an average of $22.67 \mathrm{Mg} \mathrm{ha}^{-1}$.

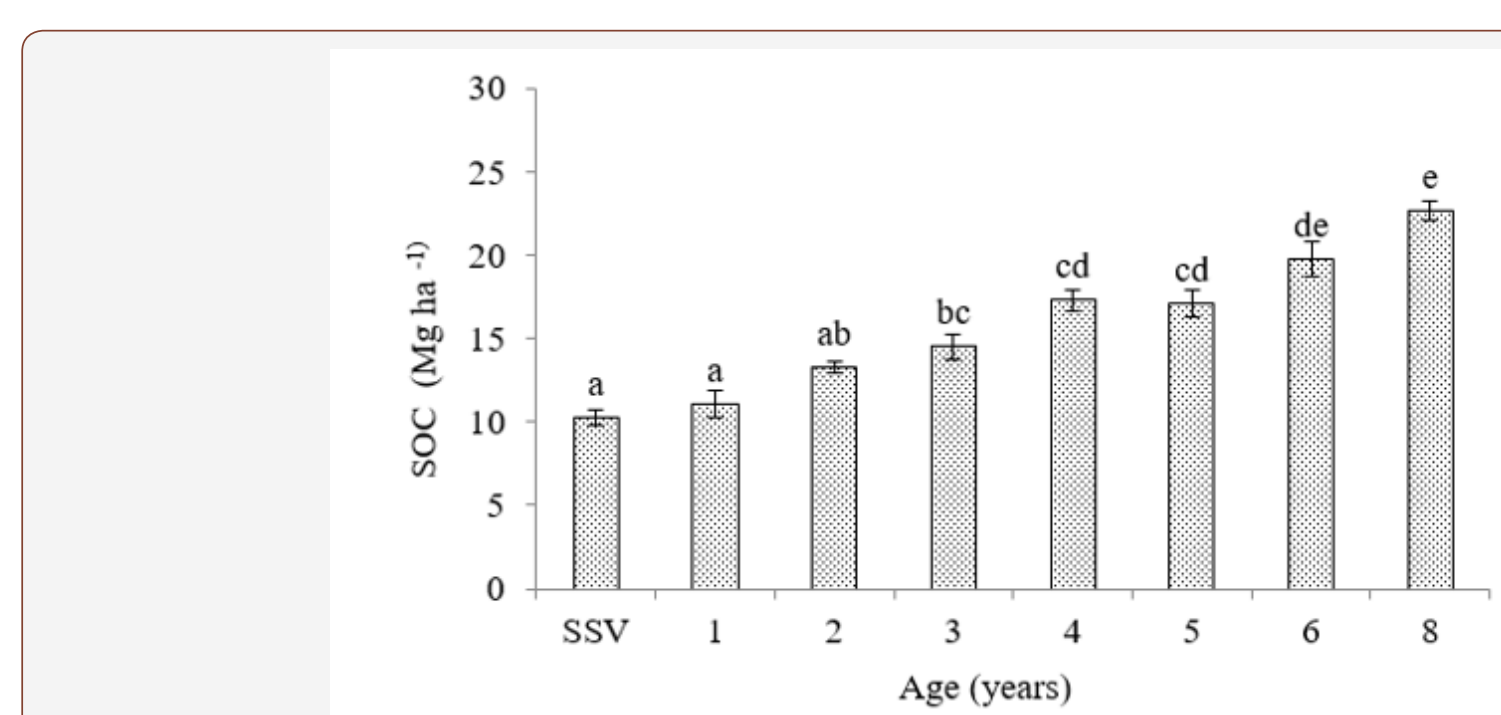

Figure 8: Organic carbon $(\mathrm{OC})$ in soils associated with reforestation of Pinus greggii of different ages (1 to 8 years) in the Mixteca Alta of Oaxaca, Mexico at a depth of $0-10 \mathrm{~cm}$. The bars show the mean \pm standard error. Columns with different letters are statistically different (Tukey, $\mathrm{P}<0.05)$.

In general, an increase in SOC is observed in the soil as the age of the reforestations increases, finding a significant difference between soils with area with scare vegetation (ASV) and soils associated with reforestation from 3 years onwards. The incorporation of new carbon is attributed to the contributions to the soil made by reforestation through litter [15]. Something similar was found by Gómez-Díaz et al., [23] in an oak forest, where the carbon stores of the forest floor increased considerably as the forest becomes larger.

\section{Conclusion}

Aerial biomass production and aerial carbon content are closely and positively related to age, that is, they increased with chrono sequence; and to a lesser extent with the degree of slope. In the case of soil organic carbon, they are closely and positively related to age, that is, increased with chrono sequence. However, an effect of the degree of slope was not found. This may be due to the fact that in this study the slope grades are not very marked or because they are degraded soils and both high and low slopes start from the same soil organic carbon (SOC) content [42].

Although, reforestations are considered monocultures, they are an extremely important alternative when there are not enough economic resources to use other recovery strategies for degraded areas. The present study shows the capacity of reforestations, to store and capture carbon in biomass and in the soil seen as a service that provides reforestation (Extra Figure). 

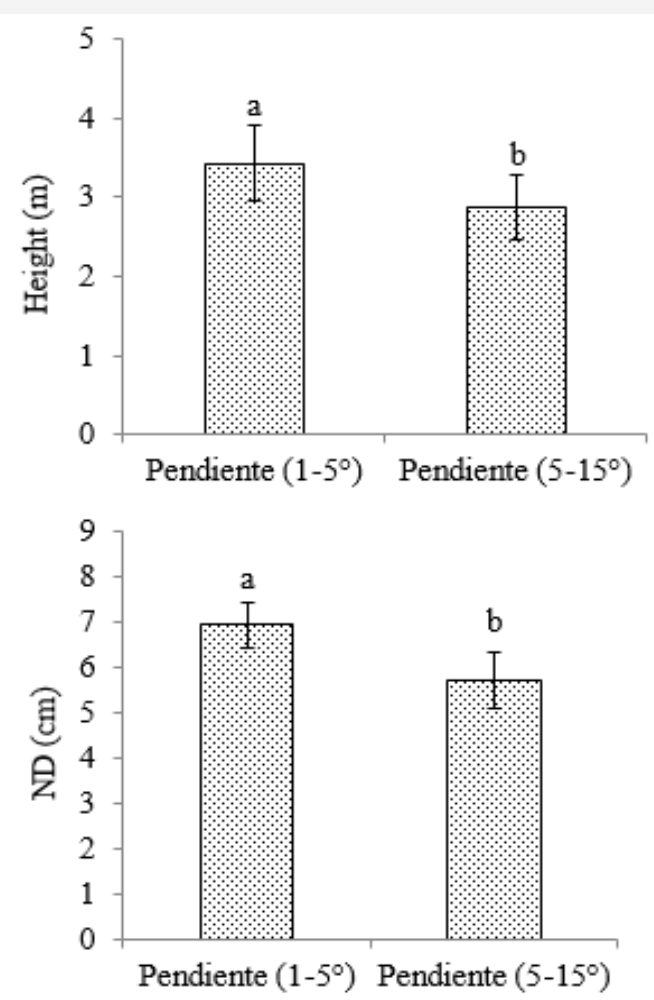

Figure 9

\section{Acknowledgement}

None.

\section{Conflict of Interest}

No conflict of interest.

\section{References}

1. Walkley A, IA Black (1934) An examination of the Degthareff method for determining soil organic and a proposed modification of chromic acid titration method. Soil Sci 37(1): 29-38.

2. Semarnat (2016) Informe de la Situación del Medio Ambiente en México. Compendio de Estadísticas Ambientales. Indicadores Clave, de Desempeño Ambiental y de Crecimiento Verde. Edición 2015. Semarnat, México.

3. Cotler H, CA López Y, S Martínez Trinidad (2011) ¿Cuánto nos cuesta la erosión de suelos? Aproximación a una valoración económica de la pérdida de suelos agrícolas en México. Investigación Ambiental 3: 31-43.

4. Cotler H, E Sotelo, J Domínguez, M Zorrilla, S Cortina, L Quiñones (2007) La conservación de suelos: un asunto de interés público. Gaceta Ecológica 83: 5-71.

5. Guerrero Arenas R, E Jiménez Y, H Santiago (2010) La transformación de los ecosistemas de la Mixteca Alta oaxaqueña desde el Pleistoceno Tardío hasta el Holoceno. Ciencia 40: 61-68.

6. Secretaría de Gobierno (SEGOB) (2014) Programa Nacional Forestal 2014-2018. México.

7. Comisión Nacional Forestal (CONAFOR) (2010) Prácticas de reforestación: Manual básico. Zapopan, Jalisco, México. 64 p.

8. Acosta Mireles M, J Vargas Hernández, JD Etchevers Barra, A Velásquez Martínez (2002) Estimación de la biomasa aérea mediante el uso de relaciones alométricas en seis especies arbóreas en Oaxaca, México. Agrociencia 36(6): 725-736.

9. García Oliva F, OR Masera (2004) Assessment and measurement issues related to soil carbon sequestration in lan-duse, land-use change, and forestry (LULUCF) projects under the Kyoto protocol. Climatic Change 65: $347-364$

10. Seppänen P (2002) Secuestro de carbono a través de reforestaciones de eucalipto en el trópico húmedo. Foresta veracruzana 4: 51-58.

11. Cusack D, F Montagnini (2004) The role of native plantations in recovery of understory woody diversity in degraded pasturelands of Costa Rica. Forest Ecology and Management 188: 1-15.

12. Lamb D, ED Peter, JA Parrotta (2005) Restoration of degraded tropical forest landscapes. Science 310: 1628-1632.

13. Maestre FT, J Cortina (2004) Are Pinus halepensis plantations useful as a restoration tool in semiarid Mediterranean areas? Forest Ecology and Management 198: 303-317.

14. Pattanayak SK, S Wunder, PJ Ferraro (2010) Show me the money: do payments supply environmental services in developing countries? Review of Environmental Economics and Policy 4(2): 254-274.

15. Luis Mejía S, A Gómez Guerrero, JD Etchevers Barra, G Ángeles Pérez, M López López Y, et al. (2007) Acumulación de carbono orgánico en el suelo en reforestaciones de Pinus michoacana. Agrociencia 41(7): 711721.

16. García E (1988) Modificaciones al sistema de clasificación climática de Köppen. Cuarta edición. Instituto de Geografía. Universidad Autónoma de México. México 6: 1-98.

17. Hernández Martínez J, J López Upton, J Vargas Hernández Y, J Jasso Mata (2007) Zonas semilleras de Pinus greggii var. australis en Hidalgo, México. Revista Fitotecnia Mexicana 30: 241-249.

18. Ramírez HC, JJ Vargas HY, J López U (2005) Distribución y conservación de las poblaciones naturales de Pinus greggii. Acta Botánica Mexicana 72: 1-16.

19. Pacheco Escalona FC, A Aldrete, A Gómez Guerreo, AM Fierros González, VM Cetina Alcalá Y, H Vaquera Huerta (2007) Almacenamiento de carbono en la biomasa aérea de una plantación joven de Pinus greggii Engelm. Revista Fitotecnia Mexicana 30(2): 251-254.

20. Diario Oficial de la Federación (2002) Norma Oficial Mexicana, Especificaciones de Fertilidad, Salinidad y Clasificación de Suelos, Estudio, Muestreo y Análisis (NOM-021-SEMARNAT).

21. González Molina L, JD Etchevers Barra Y, C Hidalgo Moreno (2008) Carbono en suelos de ladera: factores que deben considerase para determinar su cambio en el tiempo. Agrociencia 42(7): 741-751.

22. Muñoz lores HJ, VM Coria Avalos, JJ García Sánchez, E Velasco Bautista Y, G Martínez Molina (2012) Evaluación de una plantación de Pinus greggii Engelm. condos espaciamientos. Revista mexicana de ciencias forestales 3(11): 57-70.

23. Gómez Díaz JD, AI Monterroso Rivas, JA Tinoco Rueda y, JD Etchevers Barra (2012) Almacenes de carbono en el piso forestal de dos tipos de bosque. Terra Latinoamericana 30(2): 177-187.

24. Ramírez Contreras A, YDA Rodríguez Trejo (2004) Efecto de la calidad de la planta, exposición y micrositio en una plantación de Quercus rugosa. Revista Chapingo. Serie Ciencias Forestales y del Ambiente 10: 5-11.

25. Domínguez Calleros PA, R Rodríguez Laguna J Capulín Grande, R Razo Zárate, MA Díaz Vásquez (2017) Influencia de factores edáficos en el crecimiento de una plantación de Pinus greggii Engelm. en Santiago de Anaya, Hidalgo, México. Madera y bosques 23(2): 145-154.

26. Gómez Romero M, JC Soto Correa, JA Blanco García, C Sáenz Romero, J Villegas Y, et al. (2012) Estudio de especies de pino para restauración de sitios degradados. Agrociencia 46(8): 795-807.

27. Ventura Ríos A, FO Plascencia Escalante, P Hernández de la Rosa, G Ángeles Pérez Y, A Aldrete (2017) ¿Es la reforestación una estrategia para la rehabilitación de bosques de pino?: Una experiencia en el centro de México. Bosque 38(1): 55-66.

28. Corbett PS (2001) Carbon sequestration through rubber (Hevea) producction on grassland in Papua New Guinea. Journal of Rubber Research 4: 222-254.

29. Park A, M van Breugel, MS Ashton, M Wishnie, E Mariscal, et al. (2010) Local and regional environmental variation influences the growth 
of tropical trees in selection trials in the Republic of Panama. Forest Ecology and Management 260(1): 12-21.

30. Rodríguez Ortíz, G, A Aldrete, VA González Hernández, HM De Los Santos Posadas, A Gómez Guerrero Y, et al. (2011) ¿Afectan los aclareos la acumulación de biomasa aérea en una plantación de Pinus patula? Agrociencia 45(6): 719-732.

31. Wang JR, CDB Hawkins, T Letchford (1998) Relative growth rate and biomass allocation of paper birch (Betula papyrifera) populations under different soils moisture and nutrient regimes. Canadian Journal of Forest Research 28(1): 44-55.

32. Figueroa Navarro CM, G Ángeles Pérez, A Velázquez Martínez, HM De Los Santos-Posadas (2010) Estimación de la biomasa en un bosque bajo manejo de Pinus patula Schltdl. et Cham. en Zacualtipán, Hidalgo. Revista mexicana de ciencias forestales 1(1): 105-112.

33. West PW (2014) Growing plantation forests. $2^{\circ}$ ed. Springer. New York, USA. $304 \mathrm{p}$.

34. Oliva M, L Culqui Mirano, S Leiva, R Collazos, R Salas, HV Vásquez Y, JL Maicelo Quintana (2017) Reserva de carbono en un sistema silvopastoril compuesto de Pinus patula y herbáceas nativas. Scientia Agropecuaria 8(2): 149-157.

35. Li X, MJ Yi, Y Son, PS Park, KH Lee, et al. (2011) Biomass and carbon storage in an age-sequence of Korean pine (Pinus koraiensis) plantation forests in central Korea. Journal of Plant Biology 54(1): 33-42.

36. Chávez Aguilar G, G Ángeles Pérez, M Pérez Suárez, MA López López, E García Moya, et al. (2016) Aboveground biomass allocation in a managed forest of Pinus patula in Zacualtipán, Hidalgo, México. Madera y Bosques 22: $23-36$.

37. Sattler D, LT Murray, A Kirchner, A Lindner (2014) Influence of soil and topography on aboveground biomass accumulation and carbon stocks of afforested pastures in South East Brazil. Ecological engineering 73: 126-131.

38. Lin D, J Lai, HC Muller Landau, X Mi, K Ma (2012) Topographic variation in aboveground biomass in a subtropical evergreen broad-leaved forest in China. PloS one 7: e48244.

39. García Aguilar JÁ, G Rodríguez Ortiz Y, J Martínez de la Cruz (2015) Influencia de variables fisiográficas en la productividad de biomasa aérea en bosques mixtos. Revista Mexicana de Agroecosistemas 2(2): 87-98.

40. Castillo Pacheco LA, JI Bojórquez Serrano, A Hernández Jiménez Y, D García Paredes (2016) Contenidos de carbono orgánico en suelos bajo diferentes coberturas vegetales y de cultivo. Cultivos Tropicales 37(3): 72-78.

41. Avilés Hernández V, A Velázquez Martínez, G Angeles Pérez, J Etchevers Barra, H Santos Posadas, et al. (2009) Variación en almacenes de carbono en suelos de una toposecuencia. Agrociencia 43(5): 457- 464.

42. Gutiérrez Valencia M, L Mendizábal Hernández,J Alba Landa, J Márquez Ramírez Y, H Cruz Jiménez (2012) Evaluación de una prueba de procedencias/progenie de Pinus greggii Engelm. establecida en Villa Aldama, Veracruz, México. Foresta Veracruzana 14(2): 25-30. 